\title{
ON THE LEGAL METHOD OF THE UNIFORM COMMERCIAL CODE
}

\author{
Mitchell FrankitN*
}

I

The projet of the Uniform Commercial Code of 1950 is of the greatest importance in the history of American law, because it has given the problem of the general codification of American law certain of the significance it deserves in the United States.

However, this projet is not the first commercial code proposed in this country. About 1825 the projet of a commercial code, containing almost two thousand articles, was formulated in Louisiana. The texts were part of a general upsurge of codification, which, in part, was inspired and influenced by the history of codification in France. A series of several codes, mostly Romanist, was prepared under the leadership of Edward Livingston. The projet of the commercial code was among these codes, of which the most important was the civil code. ${ }^{1}$

The commercial code, thus prepared for Louisiana, was not given the force of law, and has been forgotten. On the other hand, the projet of the UCC makes its appearance at a time when it may be expected to precipitate general American interest in codification. The UCC comes at the end of a long period of preparation for codification of American private law. The codification thus represented by the UCC or the lex Llewellyn has its origins in two movements of American legal history. The chief of these was the movement in favor of partial "private" or partial authoritative codification, represented by the formulation of the Restatements of Law, or by the various texts of uniform state laws. It may be said that the lext Llewellyn, in so far as it is a redaction, is the present culmination of this movement. The second movement, the force of which contributes to the possibility of bestowing legal vigor on the UCC, has been the tendency in the United States to support the codification of international law, and thus the proposed code also develops out of the history of the Harvard restatements and formulations of international law. ${ }^{3}$

The UCC rests, therefore, on a solid historical development in the United States, which has undermined the force of the opposition to codification, supposedly justified by conceptions borrowed from Savigny and the jurists of the historical schools influenced by Savigny, and has put American law on the path indicated by Bacon, Bentham, and Livingston.

* A.B. 1922, Harvard College; LL.B. I925, S.J.D. 1928, Harvard University. W. R. Irby Professor of Law, Tulane University. (1937).

${ }^{1}$ Franklin, Concerning the Historic lmportance of Edward Livingston, II TULANE L. REv. 163, 210

${ }_{2}^{2}$ Franklin, The Historic Function of the American Law Institute: Restatement as Traditional to Codification, 47 HARv. L. REv. I367 (1934).

${ }^{3}$ Franklin, A Study of Interpretation in the Civil Law, 3 VAND. L. Rev. 557, 560 (1950). 
Aside, therefore, from the content of the proposed commercial code, it is of the greatest importance because it massively poses the general problem of codification of the common law. The commercial code proposed in r825 in Louisiana was formulated or redacted as a Romanist text, and as such reflected well established Romanist or civilian legal ideas. However, the lex Llewellyn makes its appearance as a projet of a code, not only within the framework of a legal history which has only very recently and only very reluctantly relented in its general prejudices against codification, but also within the framework of a legal history which is based on the common law rather than on the civil law with its tradition of codification. Hence, certain aspects of the proposed American commercial code should be considered apart from the content of the text itself.

\section{II}

The lex Llewellyn has been formulated and redacted not only during a period of Keynesian economic theory, but also with consciousness of nineteenth and twentieth century legal theory and legal science. Hence, it avoids the mechanistic conceptions of codification, such as those which may derive from distortions and vulgarizations of certain sides of the thought of Austin. The lex Llewellyn may be said to avoid, therefore, a merely military conception of codification, that is, a conception of codification regarded as a command by a political superior to a political inferior. The lex Llewellyn of course accepts the principle of the hegemony of legislative activity, expressed through texts having the force of law. The recognition of such hegemony is essential because the "uniformity" sought through giving the UCC the force of law is a principle of uniformity grounded on the uniformity of the text of the code throughout the United States. Nevertheless, the UCC does not represent what might be called a Befehlsrecht, that is, a system of law based on the military idea of a command.

The authors and redactors of the UCC avoid a Befehlsrecht by admitting certain nineteenth and twentieth century legal theory concerning the meaning of law. In accordance with such thinking, law is not only a body of texts or formulations having the force of law, as is supposed by the vulgar Austinians and Benthamites, but it also connotes recognition of the role or force of legal or professional method, as was suggested by Savigny and the German jurists of the historical school of the nineteenth century, as well as recognition of the role or force of accepted or received ideas relating to the purpose or end of law, as was suggested in the Zwecklehre of von Jhering during the same century. In this country and in this century Pound therefore understood law as comprehensively meaning the body of precepts having the force of law, legal method, and the received ideals of the legal order. The lex Llewellyn admits the role of legal method (including a conception of the sources of law) and of the mission or function or purpose of the texts thereof.

Hence, at this point, it may be reiterated that even apart from the content of the new commercial code, the projet deserves full consideration because of its recognition of the role of legal method, its conception of the sources of law, and its acceptance of the theory of purpose or final cause of the text. 


\section{III}

In a recent joint sitting of the commissions for reform of the French civil code and of the French commercial code it was agreed that in such activity "the study of comparative law cannot be neglected." The proposed American commercial code may likewise be examined from the point of view of comparative law.

Although the projet of the UCC cautiously reflects the influence of Roman and modern Roman theories of legal method, it has been less sensitive to their theories of the technique of legislation and codification. This problem cannot be pursued here, but this is one of the weakest aspects of the UCC. However, even in this connection, there has been considerable advance over the restatements and the earlier uniform laws.

For instance, Section I-IOY of the UCC stipulates that

The Rules enunciated in this Act which are not qualified by the words "unless otherwise agreed" or similar language are mandatory and may not be waived or modified by agreement.

Thus, the projet receives the basic distinction which obtains in modern Roman law between ius cogens and ius dispositivum. The motifs justify Section I-ro7, saying:

One of the purposes of this Act is to make uniform the mandatory rules governing commercial transactions.

This Act contains two types of rules: (I) Rules which are mandatory[,] that is, intended to govern the contract; (2) Rules which are intended merely to substitute for matters not expressed by the parties to the contract.

The former may not be modified or waived by agreement. The latter may be waived or modified at will. The failure by courts to distinguish between these two types of rules in interpreting prior Acts has led to complete lack of uniformity. ${ }^{6}$

Although Section I-I07 makes this important forward step, the formulation falls short of modern Romanist formulation relating to the problem. Thus, Article 1418 of the new Italian Civil Code says:

Contracts are null if they are contrary to imperative norms, unless the legislative text disposes otherwise. Contracts result in nullity for lack of one of the requisites indicated in article 1325 [consent, cause, object, form], for illicitness of cause, for illicitness of motive in the instance indicated in article 1345, and for lack of requisites in the object of the contract established in article 1346 [object must be possible, licit, determined or determinable].

Furthermore, it may be mentioned that modern Romanist procedural ideas re-

- Conmissions de réforme du code civil et du code de commerce, procès-verbal analytique, 25 Octobre 3949. TRAVAUX de LA COMMTSION DE RÉFORME DU CODE CIVIL 1948-1949 105 (1950).

See Morrison, Legislative Technique and the Problem of Suppletive and Constructive Laws, 9 TuLANB L. Rev. 544 (1935); Lenhoff, Optional Terms (Jus Dispositionm) and Required Terms (Jus Cogens) in the Law of Contracts, 45 Mich. L. Rev. 39 (1946); ANGelesco, LA TEChNioue LfGrslative EN MATIÈRE DE CODIFICATION CIVILE 574 (1930).

"Compare: ". . . the law of contracts deals only with duties defined by the expressions of the parties. . . Resco 32, comment a. See the basic formulation of Article 1764 of the Louisiana civil code. 
lating to commercial law, so far as this writer knows, seem to have made slight impression on the formulators and redactors of the UCC (though certain of them have been conscious of the impact of procedure on the content of law). For instance, it has been asked in France, during discussions of the relation between civil and commercial codes, whether a commercial code does not presuppose commercial courts. Julliot de la Morandière has raised the question whether a commercial code, distinct from a civil code, does not require the separate commercial tribunals or trial courts which exist in France. He has observed:

... that in actuality the distinction between the two codes is in close relation with the distinction between civil and commercial tribunals [ $=$ trial courts], a distinction which there is no question of suppressing. He recognized, in agreement with $M$. Houin, that the tribunals of commerce apply the rules of civil law every day without difficulty, notably in matters relating to responsibility, and that the court of appeal is introduced to control as a general jurisdiction of the second degree $\left[=\right.$ appellate court of second level] ${ }^{\top}{ }^{\top}$

\section{IV}

However, in important respects, the lex Llewellyn "displaces" the legal method of the Anglo-American common law and substitutes the legal method of the civil law. Formally, such "displacement," which is cautiously stated, represents a remarkable advance in the history of American law.

The basic text in which this development is accomplished is Section r-I02.I. This fragment provides that the code

... shall be liberally construed and applied to promote its underlying reasons, purposes and policies. One of the main purposes is to make uniform the law among the various jurisdictions.

The effect of this language is that the code not only has the force of law, but is itself a source of law. The formulation of fragment I of Section I-ro2 signifies that if the text of the code falls short of deciding the controversy or problem, the code may itself be developed or "applied to promote its underlying reasons, purposes and policies." The fragment consecrates the general process of development or unfolding the code, so that it decides by analogy what it does not control by genuine interpretation ("construction"). Other legal theorists may regard this process as extensive interpretation.

Moreover, fragment 3 of Section I-I02 not only reiterates but also exemplifies the principle of the potential or analogical force of the actual or positive texts of the lex Llewellyn. This fragment provides that

A provision of this Act which is stated to be applicable "between merchants" or otherwise to be of limited application need not be so limited when the circumstances and underlying reasons justify extending its application.

Hence, fragments I and 3 of Section I-I02 justify and legitimate the analogical development of the UCC. The text of Section r-20r.I is the fundamental text,

${ }^{7}$ See note 4 sipra. 
justifying such legal method, although it is formulated more cautiously than fragment 3. This is said because fragment 3 is merely a bold, though narrow, instance of the principle of the potential force of the code cautiously formulated in fragment I.

For the sake of the national "uniformity," which it is "one of the main purposes" of the projet to achieve, Section I-I02.I forbids or excludes particularistic-historical interpretation of the UCC, so that the national purpose or Zweck of "uniformity" of interpretation acquires a force superior to that of the particularistic law prior to the reception of the UCC. But in thus "breaking" the force of particularistic-historical interpretation by means of purposive or $Z$ weck interpretation, Section I-ro2.I also makes such $Z$ weck or aim of the UCC the source of law for the closing of gaps or of lacunae in the UCC, as such omissions are disclosed by historical development within civil society.

The motifs (the pedagogic mass of the lex Llewellyn, reminiscent of the institutes or pedagogic element in the corpus iuris of Justinian and likewise intended to have some force of law, of. Section I-I02.2) confirm that the purpose of the projet is itself a general source of law for closing gaps in the UCC. Hence, it is declared

This Act is drawn to provide flexibility so that ... it will provide its own machinery for expansion and gradual alteration. It is intended to make it possible for the law embodied in this Act to be developed by the courts in the light of unforeseen circumstances.

Consequently

This Act adopts the trend of those cases which extend the principle of a statute either to fill a gap in the language or to apply to a situation outside of the statute's explicit scope where reason and policy justify such extention.

In connection with the last statement the motifs of the UCC invoke Commercial National Bank of New Orleans v. Canal-Louisiana Bank \& Trust Co. ${ }^{8}$ as representative of the "trend," justifying the analogical development of legislative texts. However, the process of deciding legal problems by the analogical force of legislative formulations rather than by resort to the force of customary law is a marked characteristic of the Roman and modern Roman law, sharply differentiating the latter from the Anglo-American common law with its traditions of antagonism to legislation and to the potential force of legislation. The long and successful history of codification in the Roman and civil law is in no small measure the result of Romanist legal method, in accordance with which a text is both law and a source of law.

The Romanist legal method consecrated by fragments I and 3 of Section I-I02 is particularly justified when a fresh legal start, such as is indicated by the lex Llewellyn, is historically demanded. The process of deepening or of developing the legislative text analogically is an assurance that fresh and justified sources of law will be invoked instead of sources which are obsolete or historically overcome. It

${ }_{239}^{8}$ U. S. 520 (1916). 
makes possible the development of the purpose of the new text, so that such purpose controls the determination of controversies brought about by the course of social development.

\section{V}

However, considering the matter formally and without regard to the content of the UCC, the process of analogical development of codes, as consecrated by Section I-I02.I, 3 , is not always justified. In this connection, it is of course irrelevant to discuss here the problem of the exclusion of the force of analogy in criminal law. But within the scope of the lex Llewellyn itself it is permissible to discuss the problem of bounding the expansive force of the new code.

The UCC itself states limitations on resort to analogy. Section I-ro2.x stipulates that the development of the code is justified only "to promote its underlying reasons, purposes and policies." Furthermore, the motifs say that

Where the underlying reason of an express provision of the Act does not apply to a particular situation, the effect of the provision should be correspondingly limited ... Where a section is silent on a particular point, negative inference may be justified when the reason of the situation requires or justifies such inference.

From a formal point of view, the virtually boundless generosity of Section I-I02.I, 3 , in formulating such theory of the limits of the productive force of the code, could be defended, if the lex Llewellyn were a civil code and not a commercial code.

A civil code or the civil law (private law) states the content of the legal relations obtaining under a certain system of social relations. A civil code or civil law comprehensively reflects and reflects back on the totality of social relations within a given society. In the words of Article 2 of the Louisiana Civil Code, inspired by the French projet of the Year VIII (=I800), the texts of the civil code "generally relate not to solitary or singular cases, but to what passes in the ordinary course of affairs."

A general civil code, therefore, has general force and is a general source of law. A theory of the general potential or productive force of the lex Llewellyn, such as is in effect stated in Section I-I02.I, 3, would have been justified if the proposed law were a civil code, that is, a general code. Such general law would have general force and would be a general source of law.

As the civil code or the civil law has both general actual force and general potential force because of its role in civil society, a commercial code or commercial law, contrary to Section I-IO2.I, 3 of the UCC, ordinarily should have only singular actual force and exceptional potential force, in so far as the commercial code or the commercial law does not merely exemplify or particularize the civil code or civil law.

Unlike the civil law or the civil code, which dominate the totality of social relationships, the related commercial code or commercial law only controls, in a certain way, the content of the law affecting certain particular subjects of law (e.g., commerçants, bankers, etc. etc.), or certain particular subject matter of law (e.g., acts of 
commerce, negotiable instruments, etc. etc.). A commercial code or commercial law therefore presupposes "its" related actual civil code or an actual civil law. Hence, the secretariat-general of the commission for the reform of the French civil code has said

The civil code must remain the general private code, the code of commerce being limited to applications and derogations.?

Indeed, in some national states it has been questioned whether the conception of the equality of the subjects of law, which supposedly is an aspect of the idea of the rule of law, that is, of the Rechtsstaat, does not demand the complete elimination of the commercial code. Hence, the new Italian civil code of 1942 has absorbed whatever is desirable of the old Italian commercial code. The latter has been deprived of the force of law.

There is, then, in Italy today only a civil, but no commercial code of "applications and derogations." During the period prior to the introduction of the new Italian civil code the productive role of the commercial code in relation to the regime of the general civil code or civil law was thoroughly explored. ${ }^{10}$

The Italian unification of the civil and commercial codes has been studied in France, where great activity toward the preparation of new codes, civil and commercial, now exists. The secretariat-general of the commission for the reform of the civil code has asked whether the texts of the new civil and commercial codes, following the Italian example, should not be united in a single code of private law. ${ }^{11}$

However, within the United States, where there is no distinguished tradition of codification, a commercial code has been formulated even before a general civil code has been formulated or even suggested. This establishes the codified commercial law in a remarkably powerful situation in regard to the uncodified civil law to which it is connected and which it presupposes. But there has been a long tradition of the force of exceptional law during the history of Anglo-American private law, despite the supposed hegemony of the rule of law and of the common or general civil law. Anglo-American equity was an exceptional law, capable of overcoming this common or general civil law; for equity only acted if the common law remedy was inadequate. It is well known that such exceptional Anglo-American equity did not, however, merely have exceptional force in the history of Anglo-American private law; for the entire system of the general private law was veered by the exceptional chancery law. In the history of American commercial law of the nineteenth century the doctrine of Swift $v$. Tyson ${ }^{12}$ also consecrated a powerful exceptional commercial law under the regime of the American Constitution, and, indeed, the emergence of the proposed UCC cannot be understood apart from the overthrow and

\footnotetext{
- Note du secrétariat-général de la commission de réforme du code civil, in Travaux, op. cit, supra, note 4 , at 98 .

10 Bobbio, L'analogia nella logica del diritto c. 13 (I938).

${ }^{11}$ Note du secrétariat-général de la commission de réforme du code civil, in Travaux, op. cit. supra, note 4 , at 96 .

${ }^{12}$ I6 Per. I (U. S. I842).
} 
failure of Swift v. Tyson, with its similar passion for uniformity, nor apart from the economic history of the United States since the Civil War, during which concentrated economic power has developed.

\section{VI}

Ray has indicated that in a code the texts are only relatively independent of each other. ${ }^{13}$ If the different texts were absolutely independent the code would cease to be a code and would be a digest in the Anglo-American common law sense. Hence it may be reiterated that the commercial code presupposes its actual or positive civil code or civil law, and is a singular law. The potential or analogical force of the commercial code ordinarily should be correspondingly limited by the general potential force of the civil code or the civil law. Therefore, the commercial code ordinarily should have only exceptional force as a source of new law, in so far as such commercial code does not merely exemplify or particularize the civil code or civil law to which it is related. The general productive force claimed by Section I-I02.I,3 and by the motifs therof would not be consistent with ideas based on the supposed singularity of the projet of the commercial code.

The consequences of admitting the general potential force of singular law may be illustrated by Commercial National Bank of New Orleans v. Canal-Louisiana Bank \&. Trust Co., ${ }^{14}$ a case invoked in the motifs of the UCC to justify the general productive force given the code in Section I-I02. This case, decided in Igr6, concerned the force of the uniform laws in Louisiana, which also has a general civil code based largely on French law. The Supreme Court of the United States used the exceptional legal novels, that is, the uniform laws, productively and virtually ignored the texts of the Louisiana civil code and the general productive force of the latter. The result was that a "uniform" or a national decision was made by the Supreme Court, but that damage was inflicted on general and pervasive conceptions of the Louisiana civil code. From the point of view of the uniformity sought in the United States by means of the uniform laws, the determination of the Supreme Court was justified; but from the point of view of the ordre publique of Louisiana this and similar decisions are vulnerable and subject to criticism.

As has already been indicated, if the civil law is uncodified, as it is in the United States save in Louisiana and Puerto Rico, concepts of ordre publique are even more exposed to the general potential force of the proposed commercial code.

\section{VII}

Although the lex Llewellyn bears the title of a commercial code, the UCC in fact deliberately enunciates (Section I-I04) and also seeks to establish that it is not "solitary" but "general" law. The UCC thus excludes the limiting effect of the role of ordre publique, at least of unwritten ordre publique, on the potential or analogical force of the new code, other than as formulated in Section I-I02.I, 3, though such

${ }^{13}$ RAy, Essa sUr La STRUCtURE LOGIQUe DU CODE CIVIL FRANCAIS 244-253 (I926).

14 See note 8 supra. 
limitation, based on public order, might be demanded if the lex Llewellyn were only ius singulare and thus lacked general potential force.

Indeed, it is the mission of Section I-I03 to show obliquely that in relation to the actual or positive civil law the commercial code is general law and the civil law itself is singular law. The text reads that

Unless displaced by the particular provisions of this Act, the principles of law and equity, including the law merchant ... shall supplement its provisions.

Under Section I-IO3 of the lex Llewellyn the related civil law, which is here described as "supplemental" law, is in fact singular law because it is subject to being "displaced by the particular provisions" of the UCC. Among these provisions are fragments I and 3 of Section I-I02, permitting the general productive force of the UCC. Section I-r02.I, 3 are "particular" provisions of the lex Llewellyn without however having merely "singular" force. If Section I-I03 meant that each "particular" provision of the code only had "singular" force, such meaning would contradict the role of fragments $\mathrm{I}$ and 3 of Section I-IO2 in recognizing the potential or analogical force of actual or positive particular texts of the code.

However, it may seem that the phrase "particular provisions" of the code, as formulated in Section I-I03, has some limiting effect on fragments I and 3 of Section I-I02. In modern Roman or civil law a distinction is made between the analogical possibility of a text having the force of law (Gesetzesanaiogie) and the analogical possibility of a principle derived from and discovered in a plurality of texts having the force of law (Rechtsanalogie). For instance, Wolff says that from Articles 367 , $371,456,468,824,916$, 1026, and 1050 of the Austrian civil code, together with other texts, a basic general principle, relating to the protection of third persons who in good faith have given their confidence to an external state of affairs, has been derived and has been given general application. ${ }^{15}$ What Wolff treats as a basic concept was developed from the indicated group of particular articles of the Austrian civil code.

The immediate problem is, therefore, whether the process of "displacement" of "supplemental" law by "particular" provisions of the UCC means that the analogical force of "particular" texts is limited to "particular" rather than to "general" analogy inspired or developed from "particular" texts, that is, the problem is whether Section I-IO3 permits only Gesetzesanalogie and excludes Rechtsanalogie. Although the motifs of Section I-I03 justify "explicit" "displacement," it seems that the word "particular," as used in Section I-I03 does not recognize merely "particular" analogical development (Gesetzesanalogie), of which fragment 3 of Section I-IO2 perhaps is an example, but also tolerates "general" analogical development (Rechtsanalogie). This interpretation of Section I-IO3 is supported by the contextual formulation of Section I-I02.I, which unfetters the possibility of a general analogical development of the UCC on a $Z$ weck or but foundation, that is, in accordance with the "underlying reasons, purposes and policies" of the projet, as exemplified by "particular" texts of the UCC.

\footnotetext{
${ }^{15}$ WolfF, Grundriss des ÖSTERREICHISCHEN BürgerLichen Rechts 15 (4te Auf., 1948).
} 
If it is the mission of Section I-I03 to seek to establish the general actual and potential hegemony of the UCC in relation to the civil law, it is the mission of Section I-ro4, to which reference already has been made, to defend the hegemony of the new code against subsequent legislation or novels. Section I-ro4 seeks to accomplish this by stating

This Act being a general act intended as a unified coverage of its subject matter, no part of it shall be deemed to be impliedly repealed by subsequent legislation if such construction can reasonably be avoided.

Hence the UCC seems to have been given the potential or analogical force of general law in relation to existing civil or private law, and at the same time it has resources to repel the force of subsequent legislation.

VIII

The so-called uniform commercial code is therefore not only a commercial code, as this conception is understood in modern Romanist law, but also claims to be a general code, limited in force only by the content and the general potentiality of the content.

To a certain extent the content of the UCC corresponds to the content of civil codes. Indeed, French theorists say that "there is hardly a contract which cannot sometimes be civil, sometimes commercial, even both at the same time." ${ }^{\text {"16 }}$ It may be emphasized that Article 9, which is devoted to security in movable property, is concerned with basic problems of civil law. Article 2, which is concerned with the sale of movable property, is one of the basic contracts of the civil codes. Furthermore, Article 2 possesses utmost importance in regard to the general theory of contract. Because of the potential or analogical force of Article 2, as justified by Section I-I02.I, 3 and the motifs, the texts of Article 2 are essential in teaching even elementary contract law. In consequence of the possibility released by Section I-I02.I, 3 and by the motifs, the impact of the UCC on the Restatement of Contracts cannot be ignored, even though Resco formulates the general theory of contract, as the latter is understood in Anglo-American common law.

Nevertheless, the content of the UCC is in fact much more restricted than the content of the civil law or of a civil code. The enunciation of Section I-IO4 that the UCC is a "general" law means that the projet is comprehensive within its relatively confined scope, and that the texts of the UCC are interrelative and presuppose each other. As has been indicated, this principle of the interrelation of the particular texts is essential in a code.

But the enunciative phrase "general act," as used in Section I-ro4, acquires an added significance because of Section I-r03. In the discussion of Section I-I03, it has been suggested that the civil law, that is, "the principles of law and equity, including the law merchant," has been reduced to "supplemental" or singular law,

\footnotetext{
${ }^{10}$ Note du secrétariat-général de la commission de réforme du code civil, in Travaux, op. cit. supra, note 4 , at ror.
} 
so far as the UCC is concerned. If Section I-IO4 is then read in connection with Section I-I03 the enunciative phrase "general act," used in the former, connotes or suggests that the UCC is the general law because the civil law is the singular law. Because of this relationship between Section I-IO3 and Section I-IO4, the words "general act" become significant from the point of view of legal method. These words reflect on Section I-I02.I, 3 and tend further to justify the general productive or analogical force of the UCC without regard to ideas of the public order prevailing in different competences. Thus, it seems that the projet has been given general potential force, though the scope of the texts of the UCC does not coincide with the content of the entire civil law.

Because the UCC enunciates and seeks to establish that it is essentially a general code and not singular law and because Section X-102.I, 3 gives general potential force to the UCC, it may be suggested that this projet fails to satisfy certain prerequisites of such a code.

In the first place, all social forces within civil society, including trade unions, farmers' organizations, co-operatives, and consumers' groups, should have enjoyed a full and active role in the technical history of the formulation of the content of the UCC.

In the second place, the general potential force of Section I-IO2.I, 3 based on the effect of the idea of national uniformity, should have been qualified by ideas designed to defend the ordre publique of the various American political competences receiving the UCC.

\section{IX}

At this point it may be emphasized that the lex Llewellyn represents an outstanding accomplishment of American law because of its consciousness that codification cannot proceed unless it is accepted that the history of the legal method of AngloAmerican common law shows the latter to be unsuitable for a regime of systematic written legal texts; and hence that such common law legal method must be "displaced" and replaced by legal method received from the history of the legal method of the Roman and modern Roman law, which developed during many centuries of experience with codification. Furthermore, it may be emphasized that the UCC is an outstanding accomplishment of American law because it accepts nineteenth and twentieth century theories of law, expressed chiefly by Pound, which have held that law is not merely a collection of formulations, but also presupposes the role of legal or professional method (Kunst) (Savigny) in relation to such texts as well as the power of the received ideals or historical aims of such texts (Zweck) (von Jhering).

However, the UCC does not go beyond these accomplishments of nineteenth and twentieth century legal theorists, and seems to fail to take account of the present situation of legal theory relating to the role and force of legal method and of received purposes or aims.

Of the three elements of law presupposed or recognized in the UCC, two of them 
(legal method and purpose) are non-normative, non-formulated elements of law. But the legal history of the twentieth century has shown that the formulated or normative elements of a code may be subordinated by the non-normative elements, such as legal or professional method and such as purpose. For instance, the German civil code of rgoo later in the century was veered into an instrument of German National Socialism by subordinating the unchanged Weimar text of the BGB to the purposes of the National Socialist Weitanschauung. ${ }^{17}$ Hence the possibility must be envisaged that although a code may be introduced in order to overcome intolerable actual or positive unformulated law, the newly formulated code itself may in turn be subordinated to a new body of unformulated legal conceptions-to a fresh natural law, as it were.

As has been pointed out, fragment I of Section I-ro2 says that the UCC shall be "construed and applied to promote its underlying reasons, purposes and policies. One of the main purposes is to make uniform the law among the various jurisdictions."

It is certainly correct to create a legal system, the aim of which is to achieve uniformity of determination. However, the aim of uniformity may become, in view of American economic history of recent decades, merely a means to other ends. If the code is a means to an end, such end may become also a means to further ends, grounded in social history. The final cause is also an efficient cause. Certainly, the aim of uniformity is in itself abstract, formal or empty, unless such uniformity is a means to the ends rooted in American social history. The possibility should be considered that the national uniformity now sought by the UCC could result in the establishment of or justification for a national hegemony characterized as a uniformity. Such uniformity might be repelled if Section I-I02 were qualified to admit the role of the public order of the particular jurisdictions receiving the UCC.

\section{$\mathrm{X}$}

Moreover, the lex Llewellyn fails to take account of twentieth century legal history relating to the role of legal method in invisibly reformulating formulated texts. Following Montesquieu, Kant had absolutely differentiated the making of law from the interpretation of law. However, it became possible after Hegel to understand that the Kantian distinction was only relative, and that the distinction even could collapse, so that the interpreter of law also became the maker of law. Certain American constitutional law confirmed this understanding. The appearance of certain schools and sects of American pragmatic legal theory, including legal realism, essentially confirmed and also justified such hegemony of legal method over the formulated text. On the other hand, during the middle of the twentieth century, Article 27 of the Charter of the United Nations was designed to prevent the subordination of the text of the Charter by means of interpretation. Therefore, Article 27 states a principle of permanent concurrence among the permanent members of

${ }^{17}$ Franklin, The Legal System of Occupied Germany, in INTERPRETATIONS of Modern Legut. Phim,osophies; Essays in Honor of Roscoe Pound 262 (Sayre ed. I947). 
the Security Council, so that their concurrence is required not only in the formulation, but also in the interpretation and administration of texts.

The American pragmatic jurists seem to have been the dominant force in formulating the lex Llewellyn. Hence their problem is whether they have accomplished as codifiers the codification which as legal theorists they have indicated could not be effectively done. As codifiers they demand uniformity in permanence, that is, they demand not only the uniform text, but also uniform interpretation, uniform administration (save in regard to suppletive texts, abstract universals, elastic clauses, standards, and the like), and uniform development of the text to control historically new problems. However, as jurists they have subordinated texts to the power of the interpreter.

The authors and redactors of the lex Llewellyn have, it is true, wrestled with their problem of achieving uniform interpretation and uniform development. Section I-I02 "displaces" the legal method of the common law and substitutes the legal method of the modern Roman law. But such change of legal method by no means guarantees uniform interpretation. Indeed, theories relating to the hegemony of legal method over the written formulation have been justified by the history of Roman and modern Roman law as well as by the history of Anglo-American common law. Furthermore, as legal method is professional method, it is the element of law historically least sensitive to the legislative power. Thus, the BGB has no texts relating to legal method, including theory of interpretation.

Fragment 2 of Section I-I02 is directed toward achieving uniformity of interpretation and development of the UCC. It provides that the motifs ("Official Comments") of the National Conference of Commissioners on Uniform State Laws and the American Law Institute may be consulted by the courts "to determine the underlying reasons, purposes and policies of this Act and may be used as a guide in its construction and application." However, recognition of the role of the motifs in achieving uniform interpretation will not exclude the development of scientific or doctrinal writing and the emergence of rival uniform interpretation.

Section I-I02 may not be adequate to achieve and to enforce uniform interpretation and development of the iex Llewellyn. It is ventured that the desired uniformity, acquiring the force of law, can be more effectively realized by means of an appropriate cassational or inspectional organization created by the political competences accepting the UCC and approved by the Congress under the compact clause of the Constitution. ${ }^{18}$ Of course the necessary apparatus for achieving uniformity of interpretation within the federal courts and for the federal courts already exists.

XI

The following theses, relating to the projet of the UCC, are ventured:

(I). The projet introduces the period of the codification of American law.

"U. S. Cosst. Art. I, \$10, fi3. 
(2). The projet shows awareness of the technique of codification and legislation of the modern Roman law, but has not been sufficiently influenced thereby.

(3). Section I-I02.I, 3 of the projet cautiously replaces the legal method of the Anglo-American common law with the legal method developed in Roman and modern Roman law, not only in regard to genuine interpretation, but also in regard to the use of the code itself as a general source of law to solve new problems.

(4). However, because the projet of the UCC claims general force and general potential force, such general potential or analogical force of the code should be subject to the ordre publique of the various political competences promulgating the text.

(5). Moreover, the projet should be followed by the preparation of a general civil code, which is justified by the existence of a commercial code, and which is made a necessity by the general potential force of Section I-I02.I, 3.

(6). Although the projet represents uniformity of formulation of texts, so far as this has been desired, it may not achieve uniformity in permanence; that is, it may not achieve uniformity of interpretation or of development. 
